\title{
Socioenvironmental issues of river bed material extraction in the Himalayan piedmont (India)
}

\author{
Łukasz Wiejaczka ${ }^{1}$ (D) $\cdot$ Lakpa Tamang $^{2} \cdot$ Danuta Piróg $^{3} \cdot$ Paweł Prokop $^{1}$
}

Received: 27 March 2018 / Accepted: 3 October 2018 / Published online: 15 October 2018

(c) The Author(s) 2018

\begin{abstract}
The present study focuses on the Balason river running through the Himalayan piedmont zone (near Siliguri, India). The objective of the study is an assessment of the environmental effects of river bed material extraction by humans and the dependence of indigenous people on the river and its ecosystem services. The analysis is based on results of field work consisting of geodetic measurements of the river channel and interviews among the local community from the Nimtijot village. Historical hydrological data were also used for the study. The results of the investigation show that the Balason river is heavily affected by excessive exploitation of river bed material during dry season and the replenishment of extracted material in a monsoon season is not always sufficient. It leads to channel deepening. The local community working in the river heavily depends for its livelihood on continuing this activity. A decreasing amount of bed material to be extracted may lead to degradation of the strong relationship between the local community and their natural environment (river).
\end{abstract}

Keywords River $\cdot$ Extraction $\cdot$ Local communities $\cdot$ Ecosystem services $\cdot$ India

\section{Introduction}

Human societies derive many essential goods from natural ecosystems through human activity in the natural environment (Alexander et al. 1997; Goudie 2000). The benefits that people obtain from ecosystems are usually referred to

Electronic supplementary material The online version of this article (https://doi.org/10.1007/s12665-018-7897-1) contains supplementary material, which is available to authorized users.

Łukasz Wiejaczka

wieja@zg.pan.krakow.pl

Lakpa Tamang

tamanglakpa@gmail.com

Danuta Piróg

dbutryn@up.krakow.pl

Paweł Prokop

pawel@zg.pan.krakow.pl

1 Institute of Geography and Spatial Organization, Polish Academy of Sciences, Jana 22, 31-018 Kraków, Poland

2 Department of Geography, Calcutta University, 35, Ballygunge Circular Road, Kolkata 700 019, India

3 Institute of Geography, Pedagogical University at Kraków, Podchorążych 2, 30-084 Kraków, Poland as ecosystem services (Costanza et al. 1995; MEA 2005). Many human activities can modify natural ecosystems leading to deterioration of ecosystem services whose value, in the long term, dwarfs the short-term economic benefits which society gains from those activities (Alexander et al. 1997; Costanza et al. 2013).

Rivers are a key source of ecosystem services such as water, food, energy, rocks, etc. (Postel and Thompson 2005; Wang et al. 2009; Auerbach et al. 2014; Rasul 2014). Within those ecosystem services, the extraction of river bed material is one of particularly important types of human activity in river ecosystems (Gregory 2006; Wohl 2006). Sand and gravel mining has been a serious environmental problem around the globe in recent years (Musah and Barkarson 2009). Instream mining directly alters the channel geometry and bed elevation. By removing sediment from the channel, instream material extraction disrupts the preexisting balance between sediment supply and transporting capacity, typically inducing incision upstream and downstream of the extraction site (Kondolf 1997; Jia et al. 2006; Huang et al. 2014). The resultant incision alters the frequency of floodplain inundation along the river courses, lowers valley floor water tables and frequently leads to destruction of bridges and channelisation structures. It also results in the loss or impoverishment of 
aquatic and riparian habitats (Rinaldi et al. 2005; Boudaghpour and Monfared 2008).

River bed material mining is a significant parameter of economic development and social welfare function in modern societies (Podimata and Yannopoulos 2016). In developing countries, mining and dredging regulations are often established without understanding of the consequences, and projects are carried out without environmental impact assessments (Peduzzi 2014). Mass-scale instream extraction by local communities leads to a progressive degradation of river ecosystems. Therefore, in order to protect them, the extraction needs to be monitored, but also the local communities' environmental and socio-economic problems need to be identified (Padmalal et al. 2008).

Environmental sensitivity and social resilience determine the balance that must be addressed between social and ecological resources in order to understand the human-environment relation. The challenge, therefore, is to combine social and environmental data in meaningful ways, which nevertheless respect the differences between these types of systems (Fraser et al. 2003).

The Himalaya is a source of material transported downstream by river surges and deposited in their piedmont. Consequently, the immediate Himalayan piedmont is an area where river bed sediments are intensively extracted. Geomorphological effects of this type of human pressure in this region have been presented in various studies. Among north Indian rivers, the Balason is the one with the most extensive body of research in this respect (e.g., De 2010; Tamang and Mandal 2011, 2015; Tamang 2013). However, there is a lack of socio-economic studies on local communities residing near rivers and exploiting their ecosystem services through river bed material extraction. This is despite the fact that people's readiness to either engage in this type of work or seek an alternative livelihood is often a determinant of the scale of human pressure on the environment. This is closely related to the social capital, the degree of people's satisfaction with the work, and their self-assessed prospects of finding a different job ( $\mathrm{Ng}$ et al. 2007).

The subject of the present study is the Balason river in the Himalayan piedmont, near the city of Siliguri (Darjeeling District in the West Bengal state), and the local community, living mainly off extracting river bed material.

The key objectives of the study are investigation of the:

a) interaction between the local community and its dependence on river bed material and its ecosystem services;

b) envoronmental effects arising out of river bed material extraction by the local community; and

c) evaluation of the prospects of continued river bed material extraction by the local community.

\section{Study area}

The Balason river is a major right-bank tributary of the Mahananda river (in the Ganga Basin) with a total length of about $48.4 \mathrm{~km}$, of which $24.27 \mathrm{~km}$ is in the hills covering about $269.89 \mathrm{~km}^{2}$ of watershed area and the remaining length of $24.13 \mathrm{~km}$ covers $97.53 \mathrm{~km}^{2}$ of lower basin area. Its source is located in the Darjeeling Himalaya at an altitude of $2361 \mathrm{~m}$ a.s.1. The outlet of the Balason river from the Himalaya starts at an altitude of $305 \mathrm{~m}$ a.s.l. and from this area onwards mostly transportation and deposition of sediment by the river is observed. The elevation of the Balason river at the confluence with the Mahananda river is $103 \mathrm{~m}$ a.s.l. The average annual discharge of the river at the piedmont is $28 \mathrm{~m}^{3} \mathrm{~s}^{-1}$. The monsoon period accounts for more than $90 \%$ of the total annual flow of water and sediment. The piedmont part of the catchment is built of sand and gravel deposits transported from the mountains.

The rainfall increases from $2000 \mathrm{~mm}$ in the Himalayan piedmont to $5000 \mathrm{~mm}$ in the southern foothills of the Darjeeling and then decreases to below $3000 \mathrm{~mm}$ at the highest peaks located $10 \mathrm{~km}$ north of the southern edge of the mountains. The winter is usually dry (Starkel et al. 2008; Prokop and Walanus 2017). Thick alluvial cover create good conditions for water infiltration and during the winter the Balason channel is also dry (Prokop and Walanus 2017).

Until 1835, the area was covered with dense natural forests. The construction of the Hill Cart Road led to deforestation, establishment of tea plantations, development of agriculture and emergence of settlement sites (Sarkel and Basu 2000; Prokop and Płoskonka 2014). At present, the forest covers $26 \%$ of the Balason catchment and is mostly limited to its northern part (Lama 2003). Reduction of the natural forest, combined with heavy rainfalls as well as the consequent high erosivity, frequent landslides and flash floods have favoured the Balason river to bring large quantities of sediment from the Himalaya and deposit it in its lower course (Basu and Sarkar 1990). This sediment can be easily extracted directly from the river bed due to its erosive nature and does not require much processing, thus providing an ideal source for growing construction industries of the region.

Along with the development of the town of Siliguri as a major transport and trade hub, with its population growing from 33,000 in 1951 to 513,000 in 2011 (Census of India 1951, 2011), the clearance of forest and expansion of settlements to cater for the increasing population has led to increased utilisation of (i.e., pressure on) river ecosystem services. In this process, the water resources from the local rivers have supported the basic needs of the region. Besides that, with the growth of settlement 
and expansion of Siliguri, the demand for construction materials has increased manifold, which has stimulated the extraction of construction materials directly from the river bed and also from the adjoining floodplains and river terraces. River bed material is extracted from almost all of the Himalayan rivers of the region, but the extent of this extraction in the Balason river is one of the largest (Supplementary material Photo 1) (Tamang and Mandal 2015).

In India, extraction of material from the river bed requires a mining permit and land lease, granted on the condition that a minimum fixed-rate royalty be paid to the State Government even if no actual extraction has taken place in the year in question. Illegal mining is punishable by imprisonment. Initially, the lease of land for extraction is granted for the period of 5 years, renewable to a maximum of 20 years. The period of extraction extends from several days to a maximum of 3 months, which may be renewed. During 2008-2010, according to the official records of the District Land and Land Reform Office in Darjeeling, there were a total of 37 Quarry Permits and 21 of these permit holders operated at the lower course of the Balason riverbed (Tamang and Mandal 2010).

On the extraction sites in the Balason river, rock fragments with size of up to $2 \mathrm{~m}$ are extracted from the river bed between post-monsoon and pre-monsoon seasons; larger boulders are broken into smaller sizes. During the monsoon season, mostly larger boulders and gravel brought down by the flow are extracted near the banks. Instream extraction is limited in this period as the river becomes inaccessible because of the increased channel flow (Tamang and Mandal 2015).

\section{Materials and methods}

The assessment of the environmental effects of the Balason river bed material extraction is based on field research conducted between 2008 and 2010. The field work was concentrated on the assessment of morphological changes in the lower Balason river bed over $24.13 \mathrm{~km}$ of its course. For this purpose geodetic measurements of the particular reach was done taking into consideration the cross sections both in the pre-monsoon and post-monsoon seasons. The results of the field research have been supplemented with an analysis of 1990-2010 annual absolute minimum and maximum water levels as well as discharges of the Balason river at the Matigara gauging station, made available by the Government of India's Central Water Commission (CWC), (Fig. 1). The lowest water level in a given year well reflects the river bed level position in the dry season when the discharge usually disappears (Klimek 1987; Wiejaczka and Kijowska-Strugała 2015). Such long-term data provide reliable information on the balance between the supply of sediment from the
Himalayas and its extraction by people above the gauging station. Figures on the quantities of river bed material extracted from the Balason between 2002 and 2010, made available by District Land \& Land Reform Office, Darjeeling have also been used.

For the socio-economic analysis of the local community and its relation with the river ecosystem, the village of Nimtijot under Matigara block, located on the Balason, was selected (Fig. 1). Most of its inhabitants live off the river bed material extraction. The village is one of several settlements located immediately near the Balason. Information on the local community's social and economic standing and its relation with the river ecosystem were collected through a diagnostic survey in the form of interview. Face-to-face interviews with the support of a local interpreter (one of the authors of this study) were conducted in November 2015.

Given the research objective, ten survey questions were formulated within three thematic groups. The issues touched upon in the interview (besides questions relating to the respondents' selected social capital characteristics, such as gender, age, education level, and number of persons in the household) focused on the intensity and (diverse) types of the local people's relation with the river, their self-assessed prospects of having a livelihood other than river bed material extraction, and their satisfaction with this work. The survey included all 53 families living in Nimtijot, which, according to the survey results, numbered 212 inhabitants. 39 people agreed to represent their families in the survey, which corresponds to the response rate of $73.6 \%$. The interviewees included 23 females and 16 males. The homes of the respondents were located in close vicinity (between 50 and $200 \mathrm{~m}$ ) from the Balason river bed. The river course section where the respondents worked was leased by a private entrepreneur.

\section{Results}

\section{Environmental effects of river bed material extraction by man}

The quantity of river bed material extracted annually from about $24 \mathrm{~km}$ of the lower river course fluctuates between approximately 3 and 14 million cubic metres (Fig. 2) what gives on average $6.8 \mathrm{~m}^{3} \times 10^{6}$ per a year. Such a substantial extraction results in an observable deepening of the river bed. The clear incision trend of the Balason river bed is revealed in the analysis of absolute minimum and maximum annual water levels in the river at CWC gauging station at Matigara Bridge for multi years period (Figs. 1, 3). For example in 1992, the lowest water level was observed in April at $121.94 \mathrm{~m}$ a.s.l., with the discharge of $0.83 \mathrm{~m}^{3} \mathrm{~s}^{-1}$. In 2010, with the discharge being similar, the water level was at 


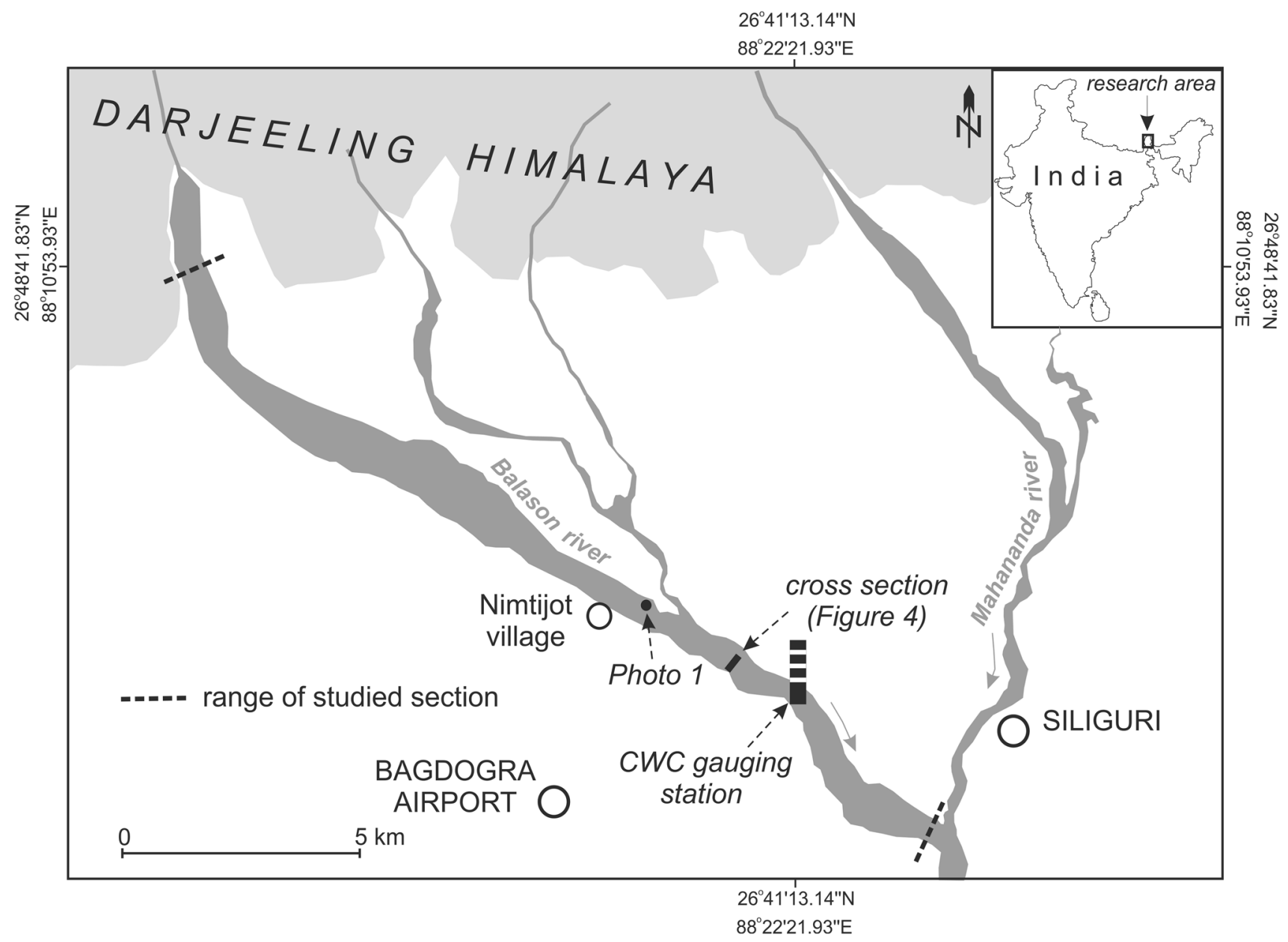

Fig. 1 Study area

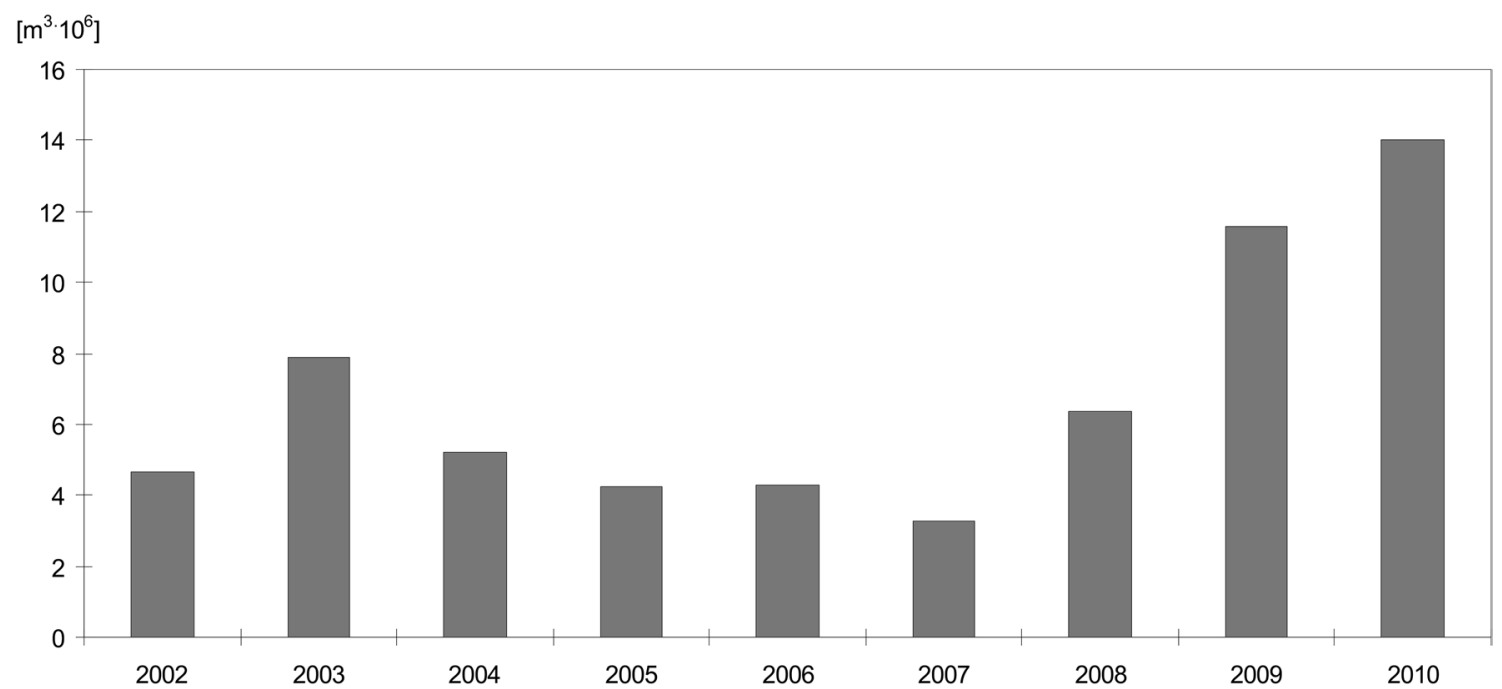

Fig. 2 Total volume $\left(\mathrm{m}^{3} \times 10^{6}\right)$ of river bed material extracted from the lower course of the Balason river during 2002-2010 


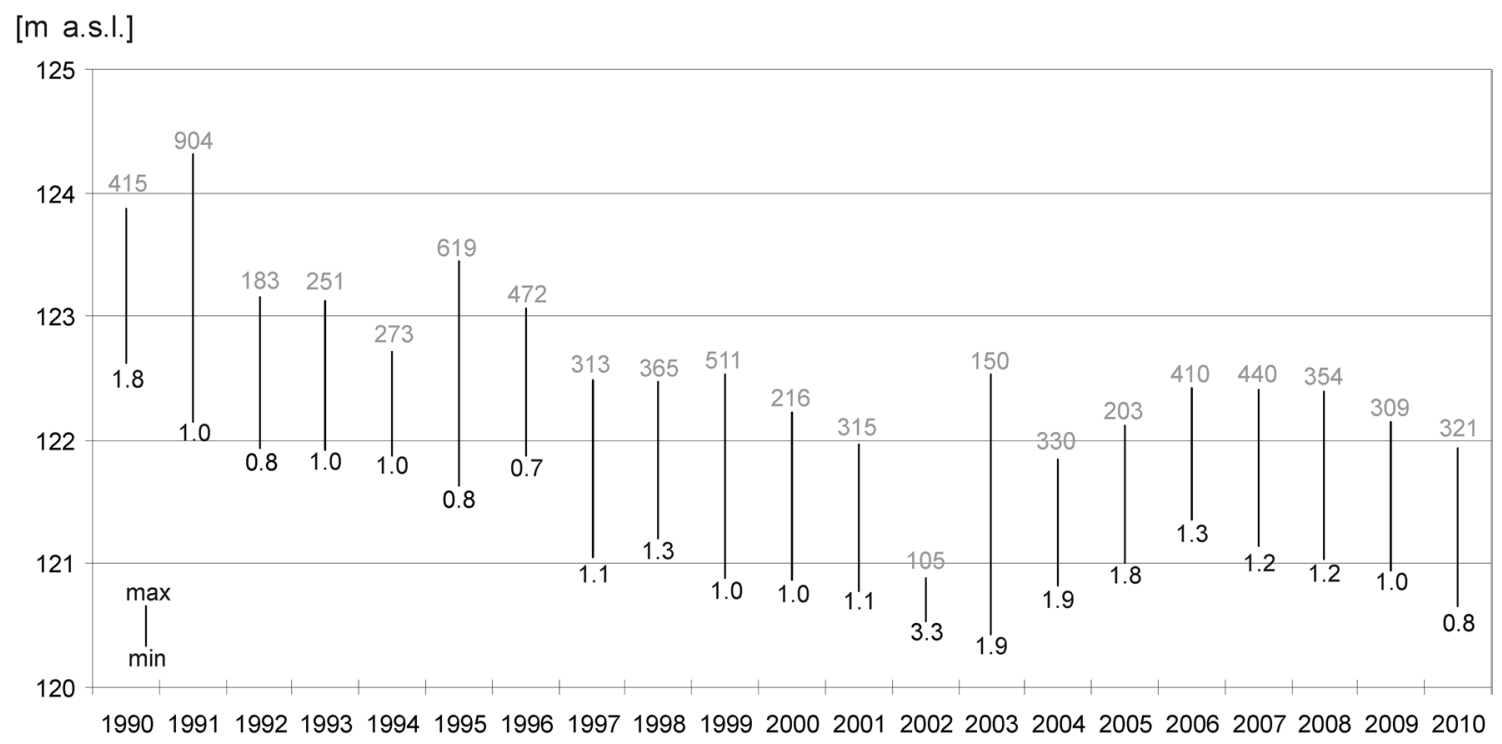

Fig. 3 Minimum and maximum water levels in the lower Balason river (with examples of max-min discharge values in $\mathrm{m}^{3} \mathrm{~s}^{-1}$ ) after data of CWC gauging station

$120.66 \mathrm{~m}$ a.s.1.; thus, within less than 20 years, the Balason river bed level had lowered by $1.3 \mathrm{~m}$ (approx. $7 \mathrm{~cm}$ per year). The observed deepening trend of the Balason river bed at the Himalayan piedmont is further confirmed by an analysis of maximum annual water levels in similar time intervals. While in August 1990, with the discharge of $415.20 \mathrm{~m}^{3} \mathrm{~s}^{-1}$, the maximum annual water level reached $123.87 \mathrm{~m}$ a.s.1., during the 2006 monsoon the water level was $122.43 \mathrm{~m}$ a.s.l. with a similar discharge $\left(409.70 \mathrm{~m}^{3} \mathrm{~s}^{-1}\right)$, which corresponds to the deepening of the river bed by $1.4 \mathrm{~m}$.

The study of the cross-sections of the Balason river channel presented by Tamang and Mandal (2015) shows that the supply of material by surges during the monsoon season did not always compensate for the losses resulting from massscale extraction of river bed material during the dry season. The changes of the river bottom level are clearly observable through changes of the mean bed elevations estimated as an average value of all bed levels across the section recorded during the geodetic survey. In 2008, the mean bed elevation was $118.28 \mathrm{~m}$ a.s.1. It went down to $118.08 \mathrm{~m}$ a.s.1. in 2009 but increased again to $118.12 \mathrm{~m}$ a.s.1. in 2010 (Table 1). During 2008, in comparison to the pre-monsoon condition, the post-monsoon mean bed elevation lowered by $0.20 \mathrm{~m}$ with a maximum lowering of $1.06 \mathrm{~m}$, indicating that the replenishment of sediments by the river was not sufficient to fill the volume extracted in the previous dry season. The 2009 and 2010 measurement results show that the postmonsoon mean bed elevation increased by 0.27 and $0.29 \mathrm{~m}$, respectively. In some sections the replenishment was not sufficient since the continuous extraction rate had lowered the bed elevation. The good example of such situation is cross section of the Balason channel bed presented in Fig. 4 (see also Fig. 1). Before monsoon period the mean elevation of the channel bed in this section was $117.88 \mathrm{~m}$ a.s.l., but after the monsoon the mean bed level has lowered to $117.60 \mathrm{~m}$ a.s.l. The lowering of the channel bed in this case ranged from a few centimeters to above $1 \mathrm{~m}$.

\section{Social aspects of the river bed material extraction from the Balason river}

The majority (59.0\%) of the respondents were young people, aged 18 to 39. Among the others, those aged between 39 and 59 accounted for $38.5 \%$ and those older than 59 accounted for $2.6 \%$. As many as $64.1 \%$ were illiterate; others had completed between 3 and 10 years of education.

Over the course of the year, the respondents were busy extracting river bed material every day between the

Table 1 The Balson river bed level based on geodetic measurements (in $\mathrm{m}$ a.s.l.)

\begin{tabular}{|c|c|c|c|c|c|c|}
\hline Year & 2008 & & 2009 & & 2010 & \\
\hline Season & Pre-monsoon & Post-monsoon & Pre-monsoon & Post-monsoon & Pre-monsoon & Post-monsoon \\
\hline Sesonal mean bed level & 118.37 & 118.18 & 117.99 & 118.26 & 117.97 & 118.27 \\
\hline Annual mean bed level & 118.28 & & 118.08 & & 118.12 & \\
\hline
\end{tabular}




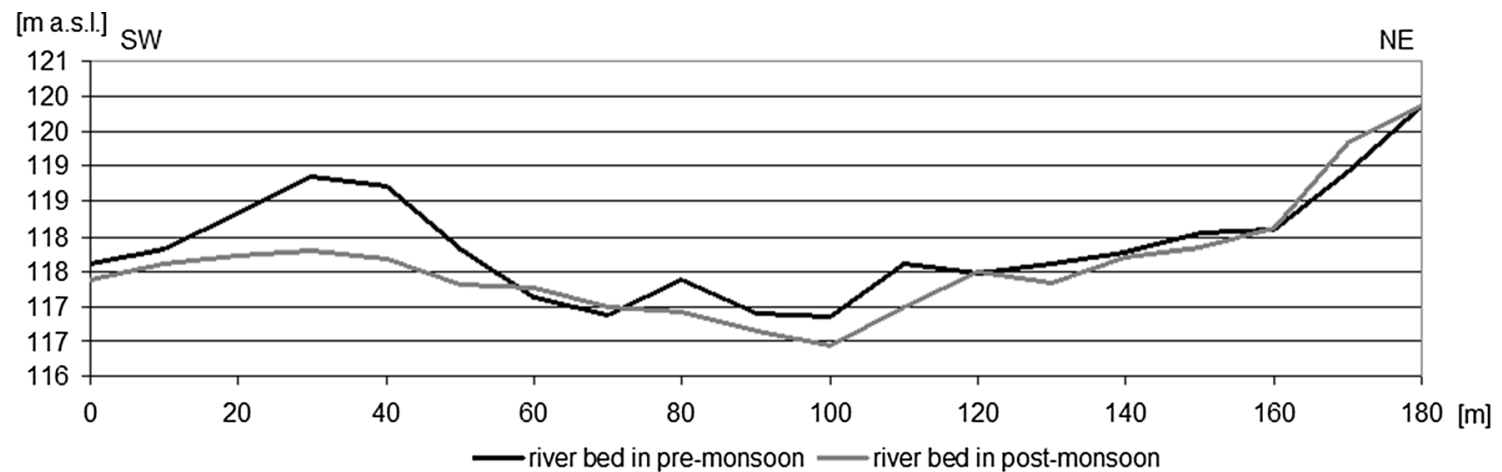

Fig. 4 Cross-section of an active (main) Balason channel (examples of morphological changes in the pre-monsoon and post-monsoon period in the 2010), (see Fig. 1)

post-monsoon season and the pre-monsoon season (i.e., from October until June). In this period, the extraction work fully determined their schedule. The respondents declared spending most of their day at the river, mostly starting their work between 8 and 9 am and finishing between 4 and 5 pm. During the monsoon season, they only worked when the water level was low enough to allow extracting material from the river bed. All the respondents declared that all they did after finishing work was resting and preparing meals.

The river not only provided the respondents with livelihood but was also the source of ecosystem services which met many of their other basic needs, such as hygiene (bathing, doing laundry) or food (e.g., fishing). The respondents unanimously declared using the river every day for such purposes.

Extracting riverbed material was nearly the sole source of income for the subjects. They had spent the average of 11 years doing this work; for individual respondents, the period ranged from 1 year up to more than 30 years. The person having spent the shortest time in the work (1 year) was a 29-year-old woman with 4 years of primary education. The one who spent the longest in the work (32 years) was a woman of 55, with 2 years of primary school.

One person was capable of extracting approx. $20-25 \mathrm{ft}^{3}$ $\left(0.6-0.7 \mathrm{~m}^{3}\right)$ of material per day, which yielded the earning of ca. INR 100 (approx. USD 2). This level of earnings only allowed the people to meet their basic needs, mostly to buy food. During the monsoon season, they mostly bought food on credit which they then repaid after they started working regularly in autumn.

Despite the earnings only allowing the people to meet their basic current needs, the respondents declared being relatively satisfied with their work of riverbed material extraction (most probably they were satisfied about having any paid work at all), (Table 2). More than half (59\%) were mostly satisfied with the work while only one-third were dissatisfied (20.5\% answered "mostly dissatisfied"; $15.4 \%$ answered "very dissatisfied").
Satisfaction levels were clearly correlated with gender. More females (69.6\%) than males (43.8\%) declared being satisfied with the work; far fewer females $(4.3 \%)$ than males (31.3\%) were very dissatisfied.

There was also a correlation, albeit smaller, between the persons' work satisfaction and their education level. More people with three or fewer completed years of education were satisfied with their work $(63.0 \%$ mostly satisfied) than those with 4 or more years (50.0\% mostly satisfied). People with more education years were also more likely to express dissatisfaction with their riverbed material extraction work (33.3\% very dissatisfied) compared with illiterate people or those with 3 or fewer years of education $(7.4 \%$ very dissatisfied).

A less pronounced correlation was also observed between age and work satisfaction: younger people (up to 39 years of age) were slightly more dissatisfied compared with the older ones.

These differences in the respondents' self-assessed satisfaction with the riverbed material extraction work were not matched with their opinions on their own prospects of finding an alternative job. The respondents unanimously thought that they had no real prospects of changing either their job or their place of residence: their experience showed that there were no other jobs available. This view, although pessimistic, seemed accurate, especially given the people's low or zero education level and their observation of there being no job vacancies in the vicinity.

\section{Discussion}

Our research on the Balason river shows that the natural supply of sediments during surges in monsoon time does not compensate for the losses resulting from the extraction of material from the river bed in a dry season. This causes the river bed to incise further into the foundation. The Balason channel deepening is well noticeable in a 


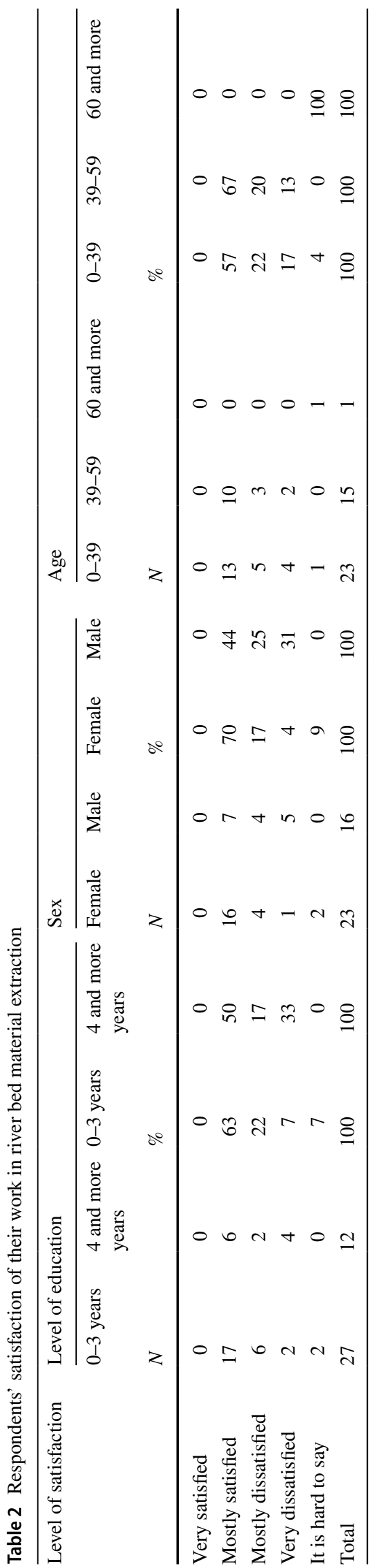

geodetic measurements (Table 1) and long term water levels and discharges analysis (Fig. 3). Similar processes are also observed in other rivers in the Himalayan piedmont (e.g., Starkel and Basu 2000; Singh et al. 2016; Wiejaczka 2016) as well as in other regions subject to this type of human pressure (e.g., Surian and Rinaldi 2003; Wyżga 2007; Martín-Vide et al. 2010). In the Balason, the morphological changes in the river bed has been confirmed by people working in the material extraction, who have reported sighting the rock foundation at the depth of 4-6 $\mathrm{m}$ from the bank top in some locations of the river bed. This indicates that the alluvial deposits in the river bed are quickly becoming depleted. This may have adverse environmental and socio-economic effects (Kondolf et al. 2002; Padmalal and Maya 2014). Parker (1996) states that any adverse effects on the hydrological environment of developing countries will tend to have a corresponding effect on the health of local communities. Research in this area has demonstrated that the lowering of the river bed results in a corresponding lowering of the water table, which causes wells in the vicinity of the river to dry out, whereupon the local communities lose their sources of drinking water (Kondolf et al. 2002; Padmalal and Maya 2014). Other reported social and economic consequences of river bed material extraction include reduced access to food (e.g., fish) and land (especially agricultural land) or loss of trees and vegetation (Padmalal and Maya 2014).

Questionnaire surveys among the local community working in extracting river bed material from the Balason showed that livelihood of these people heavily depended on the river. The imminent depletion of the river bed material made them concerned about their future. According to MEA (2005), the degradation of ecosystem services is harming many of the world's poorest people and is sometimes the principal factor causing poverty. Diminished human well-being tends to increase immediate dependence on ecosystem services, and the resultant additional pressure can damage the capacity of those ecosystems to deliver services. Since river bed material extraction is often a strong factor in the economic development of the local communities and regions, Dahal et al. (2015) believe that the riverbed extraction should be continued with special monitoring and evaluation in the areas where there is still room for extraction.

The results of the analysis suggest that continued extraction of bed material at a large scale from the Balason river bed by the people living in the vicinity can create long term problems. This is as a consequence of the following observations:

1. Low educational capital of the local people and the resulting limited prospects they have of engaging in a different work. 
2. The relative young average age of the people working currently, who have already grown accustomed to their situation and accepted it;

3. The relatively high work satisfaction;

4. The respondents' widespread belief of a lack of alternative livelihoods;

5. The genuine lack of other employers in the neighbourhood, which makes any change of livelihood problematic.

Keeping in view the changes in the morphological parameters of the channel at this particular reach of the Balason river and the need of the community as pointed out earlier, the exploitation of the river bed materials will continue. This can lead to long term degradation of the strong relationship between the local community and their natural environment (river) from where the community exploit the benefits. In the next 10-20 years, the following two scenarios may possibly emerge :1. The decreasing amount of material (observed in long-term trends of hydromorphological data) can lead to reduction in the demand for workers dealing with bed material extraction and to decrease of their earnings. As a consequence the local people seeking new forms of employment will migrate elsewhere. Ecosytsem services in the current form (the river as the main source of income) will stop functioning or be visibly limited.2. This river will still be a focus of ecosystem services for the local community. In spite of signs of bedrock exposure, the few extreme events may potentially provide huge amount of materials that can be exploited by the local dependent community.

There is every likelihood that the both the conditions may occur in future. The exploitation of bed material in the dry season with no sufficient replenishment during the monsoon season may completely drain the Balason reach's resources. From the other hand Starkel et al. (2017) report that the recent catastrophic flood in the region have occurred nearly 50 years ago (in 1968) and predict that in the coming years a similar hydrological event is expected. That event/s may provide enough materials for the local community for short-term sustenance.

In order to prevent devastation of the Balason river environment as well as other rivers in the piedmont of Himalayas where the excessive exploitation of bed material take place, the local governments (with the support of riverine ecosystems scientists) should monitor the scales of extraction and determine the amount of quarried material to maintain balance between local environment and economy. At the same time, the population whose livelihood depends on the extraction of bed material from rivers should be supported by providing other sources of income, especially during monsoon season. In a short period of time, in the light of the dynamic economic development of India, the good solution would be providing temporary jobs in building and road construction sector of fast developing Siliguri. In the long-term, it is necessary to raise the level of education of workers, which should increase the possibility of finding a job also outside of only providing raw materials for the construction sector.

\section{Conclusions}

As a summary of the above considerations concerning environmental and social problems related to river bed material extraction in the Balason river at the Himalayan piedmont, the following conclusions may be formulated:

1. The Balason is heavily affected by excessive extraction of river bed material, not compensated for in the annual scale by supply of deposits from the mountains. This leads directly to morphological changes in the river bed, including its deepening up to the point of reaching the exposure of bed rock.

2. The local community exploiting the river bed materials heavily depends for its livelihood on this activity and will still continue.

3. The results of the current work suggest that exploitation of river bed materials in this area is likely to continue till the next decade or more. However, given the imminent depletion of the river bed material, the local people might be compelled to change their place of residence, e.g., to move to so far less exploited locations upstream the Balason or other rivers, or even to seek alternative livelihoods.

Acknowledgements This paper is the outcome of research collaboration between Institute of Geography and Spatial Organization, Polish Academy of Science and the Indian National Science Academy. We express gratitude to Prof. Subir Sarkar from Department of Geography, North Bengal University, who helped in organizing fieldwork.

Open Access This article is distributed under the terms of the Creative Commons Attribution 4.0 International License (http://creativeco mmons.org/licenses/by/4.0/), which permits unrestricted use, distribution, and reproduction in any medium, provided you give appropriate credit to the original author(s) and the source, provide a link to the Creative Commons license, and indicate if changes were made.

\section{References}

Alexander S, Ehrlich PR, Goulder L, Lubchenco J, Matson PA, Mooney HA, Woodwell GM (1997) Ecosystem services: benefits supplied to human societies by natural ecosystems, vol 2. Ecological Society of America, Washington, DC

Auerbach DA, Deisenroth DB, McShane RR, McCluney KE, Poff NL (2014) Beyond the concrete: Accounting for ecosystem services from free-flowing rivers. Ecosyst Serv 10:1-5

Basu SR, Sarkar S (1990) Development of alluvial fans in the foothills of the Darjeeling Himalayas and their geomorphological and 
pedological characteristics. In: Rechocki AH, Church M (eds) Alluvial fans: a field approach. Wiley, Chichester, pp 321-333

Boudaghpour S, Monfared SAH (2008) Environmental effects of irregular extracting of gravel from river beds. In: Proceedings of the 3rd IASME/WSEAS international conference on energy and environment. World Scientific and Engineering Academy and Society (WSEAS)

Costanza R, Darge R, de Groot R, Farber S, Grasso M, Hannon B, Limburg K, Naeem S, Dutta M (1995) River Balason: A study of river behavior under human influence in the foothills of Darjeeling. Himalayan Paryavaran 3:18-21

Costanza R, de Groot R, Sutton P, van der Ploeg S, Anderson SJ, Kubiszewski I, Farber S, Dahal KR, Poudyal CP, Guragain HP (2013) Quantification of riverbed extraction and morphometric characterization of Tinau River. Nepal. Int J Eng Sci Manag 3:97-108

Dahal KR, Dhital D, Sharma CM (2015) Economic Activities Associated with Extraction of Riverbed Materials in the Tinau River, Nepal. Int J Econ Manag Sci 4:263. https://doi.org/10.4172/21626359.1000263

De SK (2010) A quantitative study of the longitudinal and cross -profiles (1989-1994) of the River Balason in the Darjeeling District of West Bengal. Indian J Geomorphol 15:67-80

Fraser ED, Mabee W, Slaymaker O (2003) Mutual vulnerability, mutual dependence: The reflexive relation between human society and the environment. Glob Environ Change 13:137-144

Goudie A (2000) The human impact on the natural environment. MIT press, Oxford

Gregory KJ (2006) The human role in changing river channels. Geomorphology 79:172-191

Huang MW, Liao JJ, Pan YW, Cheng MH (2014) Rapid channelization and incision into soft bedrock induced by human activity-Implications from the Bachang River in Taiwan. Eng Geol 177:10-24

Jia L, Luo Z, Yang Q, Ou S, Lei Y (2006) Impacts of huge amount of sand dredging on riverbed morphology and tidal dynamics of the lower reaches of the Dongjiang River and the Dongjiang River Delta. Acta Geogr Sin Chin Edn 61:985

Klimek K (1987) Man's impact on fluvial processes in the Polish Western Carpathians. Geogr Ann 69:221-226. https://doi. org/10.2307/521379

Kondolf GM (1997) PROFILE: hungry water: effects of dams and gravel mining on river channels. Environ Manag 21:533-551

Kondolf GM, Smeltzer MW, Kimball LC (2002) Freshwater gravel mining and dredging issues: white paper. Washington Department of Fish and Wildlife

Lama I (2003) Study of the environmental geomorphology in the Balason basin. North Bengal University, Siligurii

Martín-Vide JP, Ferrer-Boix C, Ollero A (2010) Incision due to gravel mining: modeling a case study from the Gállego River, Spain. Geomorphology 117:261-271

Millennium Ecosystem Assessment (2005) Ecosystems and human well-being: synthesis. Island Press, Washington, DC

Musah JA, Barkarson BH (2009) Assessment of sociological and ecological impacts of sand and gravel mining: a case study of East Gonja district (Ghana) and Gunnarsholt (Iceland). Final Project, Land Restoration Training Programme, Keldnaholt, p 112

Ng TH, Sorensen KL, Eby LT, Feldman DC (2007) Determinants of job mobility: a theoretical integration and extension. J Occup Org Psychol 80:363-386

Padmalal D, Maya K (2014) Sand mining: environmental impacts and selected case studies. Springer, Berlin, p 162

Padmalal D, Maya K, Sreebha S, Sreeja R (2008) Environmental effects of river sand mining: a case from the river catchments of Vembanad lake, Southwest coast of India. Environ Geol 54:879-889

Parker D (1996) Environmental assessment and auditing of mining operations-an international perspective. In: Proceedings of the
IBC UK conferences on the environmental management of mining operations, London

Peduzzi P (2014) Sand, rarer than one thinks. Environ Dev 11:208-218

Podimata MV, Yannopoulos PC (2016) A conceptual approach to model sand-gravel extraction from rivers based on a game theory perspective. J Environ Plan Manag 59(1):120-141

Postel SL, Thompson BH (2005) Watershed protection: Capturing the benefits of nature's water supply services. Natural Resources Forum. Blackwell Publishing, Ltd, Hoboken

Prokop P, Płoskonka D (2014) Natural and human impact on the land use and soil properties of the Sikkim Himalayas piedmont in India. J Environ Manag 138:15-23. https://doi.org/10.1016/j. jenvman.2014.01.034

Prokop P, Walanus A (2017) Impact of the Darjeeling-Bhutan Himalayan front on rainfall hazard pattern. Nat Hazards 89:387-404. https://doi.org/10.1007/s11069-017-2970-8

Rasul G (2014) Food, water, and energy security in South Asia: a nexus perspective from the Hindu Kush Himalayan region. Environ Sci Policy 39:35-48

Rinaldi M, Wyżga B, Surian N (2005) Sediment mining in alluvial channels: physical effects and management perspectives. River Res Appl 21:805-828

Singh R, Rishi MS, Sidhu N (2016) An overview of environmental impacts of riverbed mining in Himalayan Terrain of Himachal Pradesh. J Appl Geochem 18:473

Starkel L, Basu S (eds) (2000) Rains, landslides and floods in the Darjeeling Himalaya. INSA, New Delhi, 168 pp

Starkel L, Sarkar S, Soja R, Prokop P (2008) Present-day evolution of the Sikkimese-Bhutanese Himalayan piedmont. Geographical Studies Institute of Geography and Spatial Organization PAS, Warsaw, p 219

Starkel L, Wiejaczka $Ł$, Kiszka K (2017) Role of tributaries in shaping the middle course of the Himalayan River Teesta after the 1968 extreme floods. Curr Sci 112:1896-1903. https://doi.org/10.18520 /cs/v112/i09/1896-1903

Surian N, Rinaldi M (2003) Morphological response to river engineering and management in alluvial channels in Italy. Geomorphology 50:307-326

Tamang L (2013) Effects of boulder lifting on the fluvial characteristics of lower Balason basin in Darjeeling District, West Bengal. PhD Thesis, University of North Bengal, p 205

Tamang L, Mandal DK (2010) Human interferences in changing fluvial characteristics: A study in lower course of Balason river. Geogr Rev India 72:10-19

Tamang L, Mandal DK (2011) Bed material extraction and its effects on fluvial characteristic in lower Balason river in Darjeeling district, West Bengal. Analyst 1:49-54

Tamang L, Mandal DK (2015) Bed material extraction and its effects on the forms and processes of the lower Balason River in the Darjeeling Himalayas, India. Geographia Polonica 88:393-405

Wang C, Meer PVD, Peng M, Douven W, Hessel R, Dang C (2009) Ecosystem services assessment of two watersheds of Lancang River in Yunnan, China with a decision tree approach. AMBIO 38:47-54

Wiejaczka $€$ (2016) Riverbeds level changes in the margin and foreland of the Darjeeling Himalaya during the years with a normal monsoon rainfall. In: Singh R, Prokop P (eds) Environmental geography of South Asia. Springer, Japan

Wiejaczka $Ł$, Kijowska-Strugała M (2015) Dynamics of the channel beds level in mountain rivers in the light of the minimum water stages analysis. Carpath J Earth Environ Sci 10:105-112

Wohl E (2006) Human impacts to mountain streams. Geomorphology 79:217-248

Wyżga B (2007) A review on channel incision in the Polish Carpathian rivers during the 20th century. Dev Earth Surf Process 11:525-553 